\title{
Wildlife at Leaf Lake
}

\author{
K. E. Baines, Tisdale
}

$\mathbf{T}^{\mathrm{H}}$

HE American Eagles which built

a large nest in a tall poplar at the north end of Leaf Lake have apparently occupied it each year since, although it is difficult to get to during the nesting season. I walked by the nest in early December and noted that it is considerably enlarged. A year ago there were three. full grown eagles perching on dead trees during early November.

A lone swan was swimming in the open water of the river below the spillway of the dam during the first week in December. There were no ducks at all, which is unusual. Generally there are quite a few there at this time. Evidently the early freeze-up drove them all south early.

I mentioned seeing a Fisher at Leaf Lake in my last notes. One has been seen there since and two have been caught, that I know of. Fisher tracks were as common as rabbit tracks during deer-hunting season there last fall.

A trip made early last June was very interesting. Leaf Lake has been the summer home of thousands of American Coots or Mud Hens. We always used their eggs for food. This time they were rare and although we searched for hours we were not able to find a single nest. Every other type of water fowl abounds. Pelicans come there to feed but do not appear to nest there.

These birds are surely masters of air currents. While out nosing around in a canoe with a friend during the June trip, we observed three Pelicans soaring about a gunshot above us. As we were in no hurry, and the day was pleasant, we drove the canoe into some grass nearby and watched. They wheeled this way and that, and almost before we realized it they were practically beyond our vision right above us-all without a single wing-flap. My companion remarked that we were really doing things the hard way, to be paddling about in a canoe while these majestic birds could start from the same level and be several thousand feet above us while we might have covered a fewi yards.
We saw two cow moose, both with twin calves, on the way into the lake. Later wolves got one pair of calves and possibly their mother. The calves are delivered on the marshy bank of the river a mile from the timber line and never leave the immediate river bank while young.

While walking down the trail some three miles from the lake we met a large black bear. $\mathrm{He}$ was only using three legs. One front foot was doubled up and he never put it to the ground. He rose on his hind legs about sixty yards in front of us, took a good look, and turned off into the bush.

The Canada Goose seems to be using Leaf Lake a little more each year. There are large areas of floating bog completely inaccessible to man and this is where the goose rests. Sometimes he may be seen on one of the few sandy beaches, picking up gravel.

We always see the "cock of the north" or Pileated Woodpecker in this area, and, of course, ravens displace crows. There are a few straggling flocks of Sandhill Cranes and Swans but these birds are not common. Canvas-backs and Redhead Ducks are numerous in the spring and nesting season but are never encountered in the fall, all leaving during late August. Tremendous flights of Teal of both varieties arrive in early September and stay for a month or so. Pintails are almost as common as Mallards and are better eating. Bluebills are the most numerous and stay the latest.

\section{Black Swallow-Tail}

C. H. Oliver, Viceroy

Last August I had a good look at what I think is the Black Swallowtail Butterfly (Papilio Polyxenes) in my own garden.

I would like to know if any BLUE JAY readers, interested in Saskatchewan Lepidoptera have found the larva of this insect-or was it a solitary migrant from south of the border? 